\title{
Michał Mordań
}

Uniwersytet w Białymstoku

\author{
ВАРИАНТНОСТЬ ИМЕН СОБСТВЕННЫХ И ИХ \\ ГРАММАТИЧЕСКИЕ ОСОБЕННОСТИ (НА МАТЕРИАЛЕ \\ МЕТРИЧЕСКИХ ЗАПИСЕЙ СВ.-МИХАЙЛОВСКОГО ПРИХОДА \\ В Г. БЕЛЬСК ПОДЛЯШСКИЙ)
}

\begin{abstract}
SUMMARY
Variations of first names and their grammatical forms (based on metrical records of the Orthodox parish of St Michael the Archangel in Bielsk Podlaski)

This article deals with secular, colloquial, abbreviated, and other variants of first names stored in the parish metrical records as official forms of baptismal names. As informal names they reflect phonetic and morphological features of the language, allowing to distinguish them from the canonical forms, from which they were created.
\end{abstract}

Key words: linguistic, onomastics, first names, variations of first names.

\section{STRESZCZENIE}

Warianty imion własnych i ich gramatyczne osobliwości (na materiale zapisów metrykalnych parafii prawosławnej pw. św. Archanioła Michała w Bielsku Podlaskim)

Tematem artykułu są świeckie, potoczne, skrócone i inne warianty imion własnych, które wystąpiły w metrykach parafialnych w charakterze oficjalnych form imion chrzestnych. Jako postaci nieoficjalne, imiona te charakteryzują się obecnością fonetycznych i morfologicznych cech językowych, pozwalających odróżnić je od kanonicznych form kancelaryjnych, od których zostały utworzone. 
Имена людей - неотъемлемая часть истории каждого народа. В них отражается жизнь общества, а также исторические межкультурные контакты. Исследуя каждое имя собственное, необходимо учитывать культурноисторические условия данной нации ${ }^{1}$.

Имя, согласно с волей и желанием родителей, дается ребенку после его рождения и сопутствует ему (за исключением некоторых случаев) всю жизнь. Имени противопоставляется фамилия, которая может подвергаться изменению даже несколько раз. Имя обычно противопоставляется также прозвищу, которое создается в зависимости от различных обстановок и может употребляться только в определенное время. Имя собственное выполняет ряд функций и задач. Главные из них - идентифицировать человека и выделять его среди других лиц данного общества.

Особенно интересной территорией, с точки зрения ономастики и языкознания вообще, является северо-восточная часть Польши. С самого начала существования заселения на этих землях присутствуют здесь разные этносы, культуры и традиции. Поэтому и все материалы для исследований, относящиеся к этому региону, считаются ценными и интересными, хотя одновременно более сложными для анализа чем те, которые касаются территорий культурно однородных. Их сложность, кроме смешивания культур и традиций, вытекает также из самой языковой записи исследуемых источников ${ }^{2}$.

\section{1. Из истории города}

Бельск Подляшский - один из древнейших городов северо-восточной Польши ${ }^{3}$. Археологи утверждают, что его значительное развитие надо относить к VI-VII в. н. э. Значит, можно предполагать, что начало его возникновения надо искать еще раньше. В это время на берегу небольших рек Белой и Любки был основан поселок, который за недолгое время стал одним из самых выдающихся центров этой территории. Трудно определить культурно-этническую принадлежность жителей Бельска, так как с самого начала его существования присутствовали здесь разные традиции, которые

1 Por. А. В. Суслова, А. В. Суперанская, О русских именах, Ленинград 1978, s. 3-4.

2 Por. L. Citko, Nazewnictwo osobowe pótnocnego Podlasia w XVI w., Białystok 2001, s. 20. 
оказывали взаимное влияние друг на друга. Из Ипатьевской летописи мы узнаем, что в XI-XII вв. Бельск находился в пределах Киевской Руси. Начало Бельска, как града, связано с именем князя Ярослава Мудрого. В период его правления вся территория Киевской Руси переживала культурное развитие, тесно связанное с духовными ценностями. Бельск был наследником византийской, восточной традиции, так что уже в это время, кроме светских построек, возникали также церкви и монастыри. Около 1240 г. Бельск был дотла разрушен монголо-татарскими войсками. Во то время, когда град входил в состав Галичско-Волынского княжества, в Бельске была построена замковая Пречистенская церковь.

B XIII-XIV вв. Бельск принадлежал Великому Литовскому княжеству, которое, со временем, расширило свои границы, охватывая территории на запад от Бельска. Так как проживало там население, связанное с западной, римско-католической традицией, жители этих земель, переселяясь в окрестности Бельска, принесли сюда свою культуру и вероисповедание.

В 1495 г. Бельск получил городские права. Литовский князь Александр, признавший эти права, в этом же году женился на княжне Елене, дочери московского царя Ивана III и Софии Палеолог. Княжна Елена была ктитором Св.-Михайловской (по-другому Богоявленской) церкви, построенной на рубеже XV и XVI вв. Частые визиты княжны в Бельске положительно влияли на состояние храмов, находившихся в пределах города. К этому времени надо относить также экономическое развитие города. Большой вклад в развитие православия в Бельске внесла также королева Бона, которая в первой половине XVI в. основала Св.-Троицкую церковь. Во времена правления короля Сигизмунда II в городе проживало около 4 тыс. человек (по реестру 1563 г.).

В 1596 году был подписан акт Брестской унии. С тех пор церковная иерархия подчинялась религиозной политике Ватикана. Еще во время унии была восстановлена Троицкая церковь, а также два римско-католических костела и городская ратуша, которые сгорели во время пожара 1784 года.

После Третьего разбора прусские власти стремились к тому, чтобы связей православных жителей и церковной иерархии с русской церковью было как можно меньше. В этот период происходят изменения в демографическом составе горожан: кроме православных и католиков, в Бельске проживают также немцы и евреи.

3 Сведения об истории города приводятся по книге прот. Г. Сосны и Д. Феника (Zob. G. Sosna, D. Fionik, Dzieje Cerkwi w Bielsku Podlaskim, Białystok 1995), а также на основании Православного календаря за 2007 год (Kalendarz Prawosławny 2007, Wydanie Warszawskiej Metropolii Prawosławnej). 
В 1820-1830 гг. бельские приходы возвращаются из-под правления унии к православной вере, к которой они и принадлежали с самого начала своего существования.

В 60-70-е годы XIX в. в городе проживало 5800 человек, среди которых больше всех было евреев (68\%). Именно они занимались торговлей и крупным ремеслом, в то время как поляки и белорусы - земледелием и мелким ремеслом.

В результате так называемого беженства (1915 г.), большинство православных жителей Бельска эвакуировалось в Россию. Сам город особенно не пострадал. Немецкие власти не возражали против народной и культурной жизни как православных, так и католиков. В 20-е годы жители начали постепенно возвращаться из беженства. Но плохие жизненные условия способствовали разного рода эпидемиям.

В 30-е гг. ХХ в., после военного периода, Бельск продолжает развиваться с точки зрения градостроительства, экономии и населения.

Вторая Мировая война оставила свой отпечаток в жизни всех жителей Бельска, независимо от их народной и религиозной принадлежности. Власти в военный и послевоенный период по-разному относились к делам церкви и национальной принадлежности, то запрещая, то одобряя разного рода культурно-просветительские и религиозные предприятия.

В 60-е и 70-е гг. наступает миграция населения из деревень в город. В свою очередь процент родовитых горожан с каждым годом уменьшался.

В настоящее время город в быстром темпе развивается. Строятся новые дома, заводы, предприятия и другие места общественного назначения, постепенно увеличивается число жителей.

\section{2. Имена в Св.-Михайловском приходе}

Крестные имена, являющиеся предметом исследований в настоящей статье, почерпнуты из метрических книг Св.-Михайловского прихода г. Бельск Подляшский. Анализ охватывает следующие периоды: 1843-1852, 1939-1948, 1990-1999 и 2000-2009.

В годы 1843-1852 метрические книги велись исключительно на русском языке. Формы записей в периоде 1939-1948 похожи на записи XIX в., но здесь иногда проводятся они на русском, а иногда на польском языке. Встречаются также записи смешанного типа, где имена записываются по-русски (церковнославянски), а в скобках по-польски, или наоборот: по-польски, а в скобках или по-русски (церковнославянски), или русское (церковносла- 
вянское) звучание записано польскими буквами. Метрические записи периодов 1990-1999 и 2000-2009 проводятся уже на польском языке, причем в первые годы имена крещенных записывались в их светских формах, а примерно с 1992-1993 года - и на польском, и на русском (церковнославянском) языках. Иногда присутствует еще третья форма, касающаяся тех имен, которые подаются родителями в ЗАГСе, но которые отличаются от имен церковных.

\section{1. Вариантность имен}

В приходских документах основной формой имени, данного при Св. Крещении, была и есть каноническая, церковная форма. В православной Церкви требуется, чтобы крестить (а тем самым и записывать) именами православных святых, т.е. в таком виде, в котором они образовались и были в свое время приняты, зафиксированы и одобрены церковными властями. Благодаря развитию взаимоотношений Церкви и государства, министерством по делам конфессий принимались списки православных имен. Примером такого сотрудничества Церкви и государства является список имен 1936 года ${ }^{4}$.

Присутствие в метрических книгах имен исключительно в их церковных формах не является правилом, хотя устав ясно говорит, как надо их записывать: „имена рожденных писать согласно святцам, а не по устному произношению их в обыденной речи: следует писать Иоаннъ, а не Иванъ, Корнилиц̆, а не Корней (...)"

В нижеследующих подразделах приводится классификация всех вариантов имен (по отношению к исходным, церковным формам) с точки зрения сферы их употребления 6 и грамматики (фонетика и морфология).

\section{а) Формы церковные и светские}

Большинство форм церковных и светских совпадает друг с другом. Но есть такие имена, у которых эти варианты отличаются рядом черт (последние будут обсуждаться с учетом их фонетических и морфологических

4 Spis imion prawosławnych w brzmieniu polskim i staro-cerkiewno-słowiańskim, Warszawa 1936.

5 С. В. Булгаков, Настольная книга для священно-иерковно-служителей, т. II, Москва 1993 (репринтное воспроизведение издания 1913 г.), s. 973-974.

6 Классификация имен с точки зрения сферы их употребления приводится по словарю A. B. Суперанской (Zob. A. В. Суперанская, Словарь русских личных имен, Москва 1998). 
явлений $)^{7}$. В некоторых случаях в метрических записях вместо форм церковных выступают формы светские. Примерами такой замены являются имена: Алексей (<Алексий) (1851[1], 1940[1]) $)^{8}$, Ананий (<Анания) (1851[1]), Антонъ (<Антоний) ( 1844[2], 1845[1], 1846[2], 1847[1], 1850[1]), Дмитрий (<Димитрий) (1852[1]), Дементий (<Дометий) (1848[1], 1850[1]), Евласий (<Евиласий) (1850[1]), Яковъ (<Иаков) (1843[2], 1844[1], 1845[1], 1846[1], 1848[2], 1852[1]), Илья (<Илия) (1843[2], 1844[2], 1845[1]), Иванъ (<Иоанн) (1843[2], 1844[3], 1845[3], 1847[3], 1848[1], 1849[4], 1850[3], 1851[2], 1852[4]), Matwiej (<Matfiej) (1994[1]), Siergiej (<Siergij) (1946[1]), Степанъ (<Стефбан) (1843[1], 1844[2], 1846[2], 1847[1], 1850[2]), Филипъ (<Филипn) (1848[1], 1850[1]); Доминика (<Домника) (1844[2], 1845[1], 1846[1], 1848[3], 1849[1], 1850[2], 1852[2], 2000[1], 2004[1], 2009[1]), Пелагея (<Пелагия) (1850[1], 1851[1], 1852[1]), Юлия (<Иулия) (2005[1], 2006[1]).

\section{б) Формы древнецерковные}

В качестве канонических вариантов выступает несколько имен, которые в литературе определяются как формы древнецерковные 9 . В прошлом они функционировали как официальноцерковные, но после реформ начали вытесняться другими формами, которые стали считаться более правильными. Их правильность реформаторы обосновывали путем точного сравнения с формами в языках-источниках. Если принять во внимание имена греческого происхождения, то надо учесть и второе южнославянское влияние, и деятельность Максима Грека, и концепцию Москва - третий Рим, результатом которых были попытки исправления богослужебных книг, религиозной литературы и других документов церковного характера. Потому можно предполагать, что вместе с книгами, исправлению подвергались также остальные элементы православной жизни ${ }^{10}$. Реформы патриарха Никона, охватывающие ряд церковных обычаев, традиций и законов, могли касаться также форм имен. Подтверждением этого последнего может быть факт, что одной из рекомендаций патриарха было исправление формы имени Исус

7 При анализе вариантности имен с точки зрения сферы их употребления, не учитывается наличие $z$ в конечном положении в мужских формах, а также букв $i, \ddot{i}, n, b, N$, так как они являются лишь графическими особенностями.

8 В обычных скобках указывается год (годы), в котором данная форма выступает, в квадратных скобках - количество данной формы в данном году.

9 Zob. A. В. Суперанская, Словарь...

10 Por. A. Ławrinienko, Historia języka rosyjskiego, cz. II, Rzeszów 1992, s. 241, 248-249, 253, 263. 
на Иисус. Это свидетельствует о том, что изменениям могли подвергаться также и другие имена ${ }^{11}$.

Древнецерковные формы являются очень интересным явлением, так как они отражают первоначальный вид заимствованного имени (ср. Улиана - Иулиания, Устина - Иустина). Варианты, которые существуют в настоящее время, появились значительно позже, чем их предшественники. Эти формы подверглись изменению потому, что монахи, переписывавшие церковные книги, стремились придать именам более торжественную форму церковнославянского языка и сознательно их исправляли ${ }^{12}$.

В метрических записях исследуемых периодов, как варианты древнецерковные выступают следующие имена: Емиліянъ (<Емилиан) (1849[1], 1850[1], 1851[1], 1852[1]), Захарій (<Захария) (1850[1]), Иоанъ (<Иоанн) (1844[1], 1849[2]), Лукилиань (<Лукиллиан) (1847[1]); Агрипина (<Агриппина) (1843[1], 1844[1], 1847[2], 1848[1], 1849[2], 1851[1], 1852[1]), Еуфимїя $(<$ Евфимия) (1843[1]), Еуфросїнїя (<Евфросиния) (1843[1]), Катерина $(<$ Екатерина) (1846[1]).

\section{в) Формы официальные и неофициальные}

В этом месте следует противопоставить официальные формы имен (церковные и светские) и неофициальные (народные, разговорные и старокалендарные $\left.{ }^{13}\right)$. Это варианты имен, употребляемые среди народа, в семейных и дружеских отношениях.

Формы народно-разговорные: Данило (<Даниил) (1847[1], 1849[1], 1851[1], 1852[1]), Калистрать (<Каллистрат) (1850[1]), Кирило (<Кирилл) (1848[1], 1850[1]), Осипь (<Иосиф) (1843[1], 1844[1], 1846[1], 1847[2], 1848[2], 1850[2]), Петро (<Петр) (1843[1]); Іюлїя/Їюлія/Іюлія (<Иулия) (1843[1],

11 Por. L. Bazylow, Historia Rosji, t. 1, Warszawa 1985, s. 254-255.

12 Zob. А. В. Суперанская, Словарь..., s. 83.

13 Форм старокалендарных не надо отождествлять с формами древнецерковными, хотя и одни и другие не входят в настоящее время в официальные церковные святцы. Формы древнецерковные включались в Сирийский месяиеслов 411-412 гг. и в минеи XI-XIII вв. (т.е. в древние церковные источники), формы старокалендарные присутствовали в многочисленных календарях XVII-XIX вв. (por. А. В. Суперанская, Словарь..., s. 31, 93, 96). Так как этих последних не встречаем с пометой „церковное”, будем считать уместным причислить их в группу неофициальных, тем более, что они похожи на современные формы народно-разговорные (ср. папр. разг. Карпило (<Карп), Кирило (<Кирилл), Петро (<Петр), Макринья (<Макрина), Марфия (<Марба), Параскевья (<Параскева), Раисия (<Раиса), нар. Еления (<Елена) и др.). 
1850[2], 1852[2]), Марианна (<Мариамна) ${ }^{14}$ (1846[3]), Ocuna (<* Иосифа) $)^{15}$ (1851[1]), Параскевья (<Параскева) (1849[1], 1851[1], 1852[3]).

Формы старокалендарные: Марко (<Марк) (1848[1]); Параскьвїя/ Параскевія (<Параскева) (1847[1], 1850[1]).

\section{г) Смешанные формы}

Среди вариантов собственных имен, кроме вышеуказанных примеров, существует еще ряд других форм, которые трудно включить в соответствующую группу, так как они не встречаются как определенные варианты отдельных конкретных имен в доступных нам словарях (А. В. Суперанской; Н. А. Петровского; А. Н. Тихонова, Л. 3. Бояриновой, А. Г. Рыжковой). Это могут быть варианты народного и разговорного характера или формы, образованные под влиянием имен, встречающихся в других языках (в том числе польского и других западнославянских), а также в многочисленных говорах, выступающих и смешивающихся друг с другом на пограничной территории. Вследствие этих факторов, образуются разного типа гибридные формы, которые записывались в качестве официального церковного имени в метрических книгах. Ниже приводятся примеры имен этого типа, выступающие в приходских документах исследуемых периодов: Антони (<Антоний) (1851[1]), Арсении (<Арсений) (2007[1]), Григори (<Григорий) (1843[1]), Григоріи (<Григорий) (1845[1]), Демянъ (<Дамиан) (1843[1], 1845[1], 1846[1], 1850[1]), Дамян (<Дамиан) (2006[1]), Dymitry (<Dimitrij) (1939[1]), Димитрьй (<Димитрий) (1845[1]), Емеліянъ/Емелїян (<Емилиан) (1844[1], 1848[1], 1851[1]), Емелїань (<Емилиан) (1847[1]), Игнати (<Игнатий) (1844[3], 1845[1], 1846[1]), Игнатии (<Игнатий) (1850[1]), Игор (<Игорь) (2001[1], 2004[1], 2009[1]), Їюліянъ (<Иулиан) (1845[1]), Іюстынб/ ̈ююстынъ

14 Форма Марианна, засвидетельствованная в метрических книгах, является, по А. В. Суперанской (zob. A. В. Суперанская, Словарь..., s. 402), народным вариантом церковного имени Мариамна (см. Требникъ, s. 343v). В свою очередь у Н. А. Петровского имена Мариамна и Марианна выступают отдельно, причем это последнее автор толкует только как светское (zob. Н. А. Петровский, Словарь русских личньхх имен, Москва 1984, s. 150, 151).

15 Имя производное от мужского церковного имени Иосиф, причем оно здесь употреблено в народной форме (Ocun - Ocuna). Имя неправославное, не выступает ни в церковных источниках, ни даже в светских (словари А. В. Суперанской, Н. А. Петровского). Имя Осипа (или, если образовать, по аналогии, более официальную форму - Иосифа), это переводной эквивалент польского имени Józefa. Употребление такого имени в Православной церкви в таком же периоде можно объяснить влианием унии, т.е. польской католической культуры. 
$\left(<\right.$ Иустин) (1844[1], 1851[1]), Конрать (<Кондрат/Кодрат) (1845[1]) ${ }^{16}$, Костанты (<Константин) (1844[1]), Костантынъ (<Константин) (1845[1]), Корнїли (<Корнилий) (1845[1]), Ваврентий (<Лаврентий) (1849[1]), Лукиянб (<Лукиан) (1849[1]), Лукянб (<Лукиан) (1851[1]), Михайль (<Михаил) (1844[2], 1845[1], 1847[1]), Мойсей (<Мочсей) (1845[1], 1846[1], 1848[1]), Прохорій (<Прохор) (1848[1]), Сергїей (<Сергий) (1845[1]), Siemieon (<Simieon) (1939[1]), Спиридионь (<Спиридон) (1845[2]), Өтадей (<Фаддей) (1845[1], 1849[1]); Аквилина (<Акилина) (1843[1], 1844[1], 1849[1], 1850[1], $1852[1])^{17}$, Анастазія (<Анастасия) (1848[2], 1851[1]), Экатерина (<Екатерина) (1843[1]), Элена (<Елена) (1844[1]), Гелена (<Елена) (1847[1]), Есбир $(<$ Есбирь) (2004[1]), Іюлианна (<Иулиания) (1843[2]), Юліянна (<Иулиания) (1848[2]), Иулита (<Иулитта) (2000[1]), Іюлитта/Їюлитта (<Иулитта) (1844[1], 1847[1]), Іюстьна (<Иустина) (1848[1]), Іюстина (<Иустина) (1849[2]), Iustinia (<Iustina) (1992[1], 1993[2], 1995[1]), Иустиниа (<Иустина) (2001[1]), Оксенїя (<Ксения) (1844[1]), Оксеня (<Ксения) (1844[2], 1849[2]), Ксеня (<Ксения) (1850[1]), Lubow (<Lubow') (1947[2], 1948[1]), Магдалена (<Магдалина) (1844[1], 1845[1], 1849[1], 1850[1], 1851[1]) ${ }^{18}$, Макрена (<Макрина) (1845[1]), Марїянна (<Мариамна) (1845[1]), Марта (<Марфа) (1849[1]), Матреся (<Матрона) (1849[1]), аталя (<Наталия) (1844[1]), Татіяна (<Татиана) (1844[1]), Татяна (<Татиана) (1844[1], 1850[1], 1998[1]), Өекля (<Фекла) (1844[1], 1848[1]), Өтеодосія (<Феодосия) (1848[1]), Харитьна $(<$ Харитина) (1847[1]).

16 Форма Конрать может указывать на сходство не только с именами Кондрат // Кодрат, но также и с польским именем Конрад (ср. польск. Konrad), в котором-то буква д (в середине) отсутствует.

17 „Akwilina - łac. imię żeńskie; ros. odpowiedniki: Akilina, Akuilina” (Por. H. Fros, Twoje imię: przewodnik onomastyczno-hagiograficzny, Kraków 1975, s. 39).

18 Хотя некоторые священники допускают в Св. Крещении самостоятельное имя Магдалина, то надо отдавать себе отчет в том, что Магдалина - добавочное имя одной конкретной святой (Св. Равноапостольной Марии Магдалины). Поэтому самостоятельное имя Магдалина не существует (как церковное) и не должно употребляться в крещении. В настоящее время девочки, которых в ЗАГСе записывают Магдалина, в Православной церкви получают имя Мария. В годы 1843-1852 имя Магдалина выступает в качестве основного, церковного. Могло это быть вызвано влиянием унии, поскольку засвидетельствованные в метрических книгах формы (Магдалена) похожи на польский вариант. А. В. Суперанская, придерживаясь точки зрения Православной церкви, считает имя Магдалина именем светским (zob. A. B. Суперанская, Словарь..., s. 400). Имя это комментирует и Н. А. Петровский: „Магдалина В святцах было приложением к имени Мария из Магдалы (Мария-Магдалина). Затем у католиков стало употребляться в качестве личного имени" (Н. А. Петровский, Словарь..., s. 146). Интересно, что список 1936 года допускает самостоятельное имя Магдалина (zob. Spis imion prawosławnych..., s. 94). 
В исследуемом материале, вместо церковных форм, появляется, вопреки уставу, ряд нецерковных вариантов. В первую очередь надо к ним отнести формы официальные светские, которые употребляются в светских учреждениях, документах и т.д. Их можем насчитать несколько (в пределах второго десятка), поскольку во многих остальных случаях официальные формы церковные и светские совпадают. Следует заметить и наличие неофициальных вариантов, которые выступают в метрических книгах вместо официального церковного имени. Это народные и разговорные формы, распостраненные среди людей в их повседневной жизни. Отдельную группу представляют формы древнецерковные. Они в прошлом допускались Церковью, но в свое время были еще раз проанализированы и сравнены с формой в языкеисточнике, откуда были приняты и приспособлены, и, решением церковных властей, были заменены формами более правильными. Последняя, самая обширная группа - это варианты, которым трудно дать общее название. Имена эти выступают в формах смешанного типа, т.е. имеют черты народноразговорные, а также указывают на влияние других языков. При помощи разного рода фонетико-морфологических явлений образуются различные гибридные варианты имен ${ }^{19}$.

Наличие в метрических записях форм нецерковных - не очень желательное явление, приводящее к искажению правильных канонических форм, а тем самым и к уменьшению почета по отношению к покровителю, имя которого появилось в извращенном виде. С точки зрения языковедческих исследований, присутствие различных вариантов одного и того же имени доставляет нам богатый и ценный материал, а также позволяет найти ряд добавочных процессов и явлений, которые невозможно обнаружить в основных, канонических формах.

В исследуемых периодах встречается много вариантов имен, отличающихся по сравнению со своими исходными, т.е. церковными формами, рядом признаков. Для одного и того же имени встречается даже несколько таких вариантов. А. В. Суперанская замечает, что в результате многовековых и многочисленных редакций, некоторые имена получили по нескольку письменных вариантов ${ }^{20}$ (напр. Соломония, Соломонида, Саломея, Саломия;

19 Por. Н. А. Петровский, Словарь..., s. 16-17; автор этого словаря подчеркивает, что очень часто границы между отдельными вариантами имен (с точки зрения сферы употребления) бывают нечеткими, условными и подвижными.

20 А. В. Суперанская вариантами одного и того же имени считает: полные и сокращенные формы одних и тех же имен, если сокращенные варианты не попали в актовые записи (Baлентина - Валя, Тимофей - Тима); народные, церковные, диалектные, просторечные и литературные формы, если они отличаются друг от друга одной буквой в середине или в конце слова (Акулина - Акилина, Степан - Стебан); формы имен, свойственные разным диалек- 
Фелицата, Филицата, Фелицитата, Филицитата и др.) ${ }^{21}$. Формы такого типа выступают в цитируемом материале как в записях на русском языке, так и на польском. Примеры, записанные кириллицей, встречаются гораздо чаще. Есть случаи, где данное имя в своей правильной (церковной) форме не встречается ни разу, а выступает исключительно в извращенном виде (ср. напр. имена Ананій < Анания, Гарасимъ < Герасим, Ваврентий < Лаврентий, Прохорій < Прохор, Макрена < Макрина и др.). Самое большое количество этих вариантов появилось в 1843-1852 гг.

\section{2. Грамматика имен и их форм}

\section{а) Фонетические особенности собственных имен}

Фонетические процессы, отразившиеся в различных вариантах имен, по отношению к их исходным, церковным формам, тесно связаны с живой, разговорной речью, с бытом православного народа и с говорами, выступающими в белостокском регионе.

В именах исследуемых периодов встречаем следующие особенности:

a) чередование гласного:

- е > а (уподобление гласного звука в основе): Гарасим (<Герасим) (1843[1]);

- a > е: Демянь (<Дамииан) (1843[1], 1845[1], 1846[1], 1850[1]);

- и > е: Емелїанъ (<Емилиан) (1847[1]);

- о > е: Дементий (<Дометий) (1848[1], 1850[1]);

там одного и того же языка (Афанасий - Офонасий); формы имен с удвоенными буквами и без них (Филипп - Филип, Даниил - Данил); русские церковные и светские формы имен, обусловленные соответствиями норм церковнославянского и русского языков (с допускаемыми чередованиями разного типа) (Евфросиния - Ефросиния, Феофан - Фофан, Иустин - Юстин - Устин); формы с перестановками и переобразованиями групп согласных внутри имени (Флор - Фрол, Адриан - Андриан), а также формы имен, отличающиеся друг от друга написанием букв э и е (Эраст - Ераст); формы имен, отличающиеся друг от друга некоторыми конечными гласными (Алексей - Алексий, Пелагия - Пелагея); формы имен с окончанием -ий и без него (Корнилий - Корнил). В свою очередь разными считает А. В. Суперанская те имена, которые отличаются друг от друга начальными буквами (Георгий - Юрий); одной или несколькими буквами основы (Прасковья - Параскева, Симон - Семён); твердостью и мягкостью согласных, указывающих на разное происхождение имен (Вил - Виль); варианты одного и того же имени, заимствованные из разных источников (Тея - Фея, Жан - Иван); сокращенные и полные формы одного и того же имени, если сокращенные имена попали в паспортную запись (Женя - Евгений, Саша - Александр, Александра) (Por. А. В. Суперанская, Словарь..., s. 447-450).

21 Там же, s. 82. 
- а > я: Емеліянб/Емиліянб (<Емилианб) (1844[1], 1848[1], 1849[1], 1850[1], 1851[2], 1852[1]), Їюліяннб (<Иулиан) (1845[1]), Лукиянб

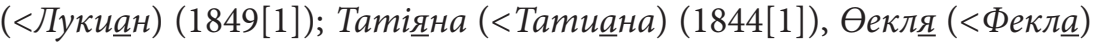
(1844[1], 1848[1]);

- у > ю: Їюліянб (<Иулианб) (1845[1]), Іюстынб (<Иустин) (1844[1], 1851[1]); Іолианна (<Иулиания) (1843[2]), Іюлитта (<Иулитта) (1844[1], 1847[1]), Іюолї (<Иулия) (1843[1], 1850[2], 1852[2]), Іотина $(<$ Иустина) (1849[2]);

б) прибавление гласного:

- е: Сергїей $(<$ Сергий) (1845[1]);

- и: Спиридионъ (<Спиридон) (1845[2]); Доминика (<Домника) (1844[2], 1845[1], 1846[1], 1848[3], 1849[1], 1850[2], 1852[2], 2000[1], 2004[1], 2009[1]), Параскевㅁ (<Параскева) (1847[1], 1850[1]), Иустинйа $(<$ Иустина) (2001[1]);

- о: ㅅсенїя (<Ксения) (1844[3], 1849[2]);

в) сокращение двойного гласного к одному:

- ии > и: Данило (<Даниил) (1847[1], 1849[1], 1851[1], 1852[1]);

г) редукция гласного:

- е: Катерина (<Екатерина) (1846[1]);

- и: Дмитрій (<Димитрий) (1852[1]), Евласий (<Евиласий) (1850[1]), Ocunz (<苂осиб) (1843[1], 1844[1], 1846[1], 1847[2], 1848[2], 1850[2]); Ксеня (<Ксения) (1850[1]), Nаталя (<Наталияя) (1844[1]), Осипа

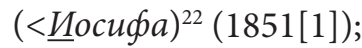

д) редукция группы гласных в один гласный (запись с йотированным гласным):

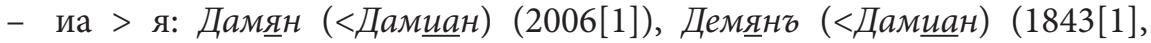

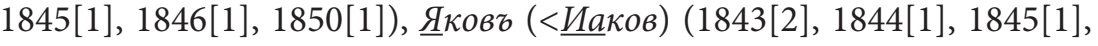

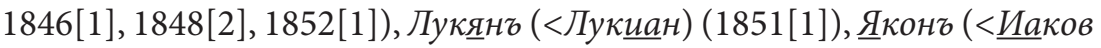
/Иакун) $)^{23}$ (1847[1]); Татяна (<Татйана) (1844[1], 1850[1], 1998[1]);

е) - потеря гласного в пользу смягчения согласного:

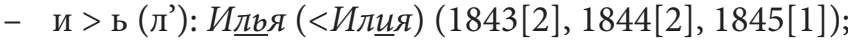

ж) переход гласного в согласный:

- о > в: Иㅁaㅎ (<И무н) (1843[2], 1844[3], 1845[3], 1847[3], 1848[1], $1849[4], 1850[3], 1851[2], 1852[4])$;

22 Имя Ocuna (*Иосифа) в Православной церкви не существует (см. выше), но с грамматической точки зрения надо его рассматривать по аналогии к имени Осun - Иосиф.

23 Процесс перехода гласных иа в я выступает независимо от того, к которой из этих исходных форм принадлежит вариант имени Яконъ. 


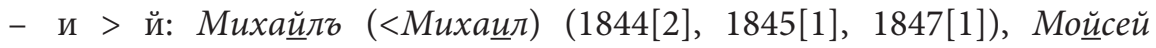
$(<$ Моисей) $(1845[1], 1846[1], 1848[1]) ;$

3) субституция согласного:

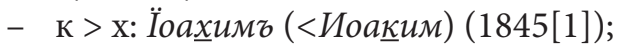

- ф > п: Ocunz (<Иосиф) (1843[1], 1844[1], 1846[1], 1847[2], 1848[2], 1850[2]), Cтепань (<Стефан) (1843[1], 1844[2], 1846[2], 1847[1], 1850[2]); Ocuna (<*Иoсифa $)^{24}(1851[1])$;

- л > в: ㅁврентій (<ㅍврентий) (1849[1]);

- с > 3 (озвончение): Анастазія (<Анастасия) (1848[2], 1851[1]);

- м > н: Марианна (<Мариамина) (1845[1], 1846[3]);

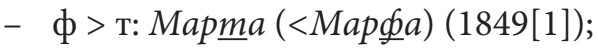

и) прибавление согласного ${ }^{25}$ :

- н: Дементий (<Дометий) (1848[1], 1850[1]);

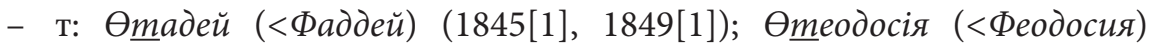
(1848[1]);

- в: Аквилина (<Акилина) (1843[1], 1844[1], 1849[1], 1850[1], 1852[1]);

к) сокращение двойного согласного к одному:

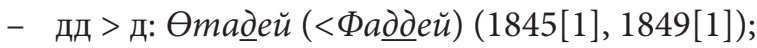

- лл > л: Кадистратъ (<Калдистрат) (1850[1]), Киридо (<Кирилд) (1848[1], 1850[1]), Лукилианъ (<Лукиллиан) (1847[1]);

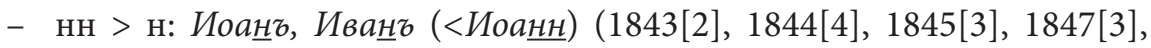
1848[1], 1849[6], 1850[3], 1851[2], 1852[4]);

- пп > п: Филипьъ (<Филипㅡ) (1848[1], 1850[1]); Агрипина (<Агрицпина) (1843[1], 1844[1], 1847[2], 1848[1], 1849[2], 1851[1], 1852[1]);

- тт > т: Иулита

л) опущение согласного:

- д: Конратъ (<Кондрат) (1845[1]) (ср. также польск. Konrad);

- н: Костантынъ, Костанты (<Константин) (1844[1], 1845[1]);

м) смягчение конечного согласного:

- p > p': Владимир'ъ (<Владимир) (1944[1]);

- л > л’: Фекл모 (<Фекл무) (1844[1], 1848[1]);

н) отвердение конечного согласного:

- p'> p: Игор (<Игорь) (2001[1], 2004[1], 2009[1]); Ecøup (<Ecøupz) $(2004[1])$

24 См. комментарий № 22.

25 Б. Тихонюк определяет это явление как „образование групп согласных из фонем двух разных форм имен, принадлежащих к чуждым друг другу именных составов”, напр. Teodora > Fteodora, Teodot > Fteodot (por. B. Tichoniuk, Imiona $i$ ich formy..., s. 25). 
о) потеря протетического j:

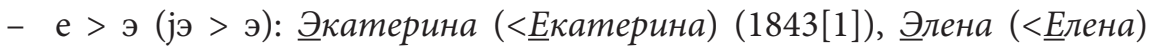
$(1844[1])$

п) прибавление протетического гласного:

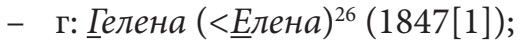

p) переход согласного в неслогообразующий гласный:

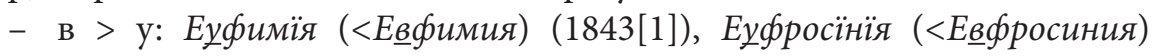
$(1843[1])$.

\section{б) Морфология собственных имен}

В этом месте следует обратить внимание на морфологические изменения, возникшие в вариантах имен, происходивших от исходных церковных форм. Это процессы, касающиеся смены парадигмы рассматриваемых антропонимов. Заключаются они в изменении конечных элементов имен собственных.

В именах собственных исследуемых периодов наблюдаются следующие изменения:

а) чередование конечных элементов:

- -ий > -ей: Алексецй (<Алексицй) (1851[1], 1940[1]);

- -ий >-и: Антонй $(<А н т о н \underline{u и ̆})(1851[1])$, Григори्u $(<$ Григорий $)(1843[1])$,

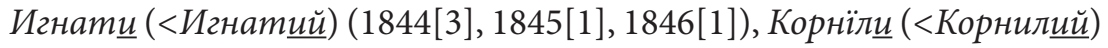
$(1845[1])$

- -ий > -ии: Арсении (<Арсений) (2007[1]), Григорйи (<Григорий) (1845[1]), Игнатіи (<Игнатицй) (1850[1]);

- -ий > -ый: Димитрыцй (<Димитрици) (1845[1]);

- -ин > -ы: Костантй (<Константин) $(1844[1])$;

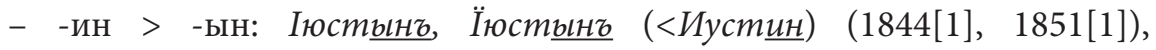

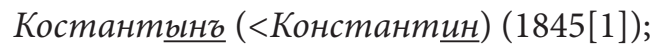

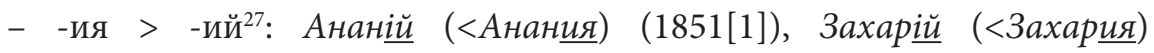
(1850[1]);

- -ия > -на: Іюлианиа, Юліянца (<Иулиания) (1843[2], 1848[2]);

- -она > -еся: Матреся $(<\text { Матрона) })^{28}(1849[1])$;

26 Произношение звука [г] в этом конкретном примере неизвестно: можно его сравнить с русским звуком [2], с белорусским $[h]$ или с польским $[h]$.

27 В этих примерах наблюдается также смешение грамматической категории рода, вызванное стремлением к унификации имен мужского рода.

28 Я. Домин перечисляет также другие имена с суффиксом -еся (-oša): Mir-oša, Mitr-oša, Jewd-oša, Tim-oša (zob. J. Domin, Z zagadnień słowotwórstwa antroponimów we współczesnym języku rosyjskim, „Zeszyty Naukowe Wydziału Humanistycznego. FR”, z. 7/1978, s. 125. Б. Тихонюк замечает, 
- -ина > -ена: Магдалена (<Магдалинна) (1844[1], 1845[1], 1849[1], 1850[1], 1851[1]), Макрена (<Макрина) (1845[1]);

- -ия > -ея: Пелагея (<Пелагия) (1850[1], 1851[1], 1852[1]), Саломея $(<$ Саломия) $(1843[1], 1850[1])$;

- -ина > -ына: Iюстициа $(<$ Иустина) $(1848[1])$, Харитициа $(<$ Харитина $)$ $(1847[1])$

б) прибавление окончания:

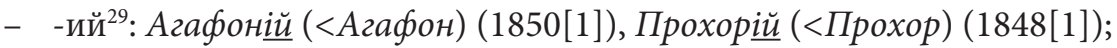

- -о: Данило (<Даниил) (1847[1], 1849[1], 1851[1], 1852[1]), Кирило $(<$ Кирилл) (1848[1], 1850[1]), Марко $(<М а р к) \quad(1848[1])$, Петрo $(<$ Петр) $(1843[1])$;

в) редукция окончания:

- ий: Антонъ (<Антоници) (1844[2], 1845[1], 1846[2], 1847[1], 1850[1]), Василь (<Василици) $(1844[1], 1846[2], 1849[1])$;

\section{3. Особенности имен собственных, записанных на польском языке}

Среди имен, выступающих в метрических книгах в польском варианте, преобладаютпримеры транскрипции, т.е.точнойпередачи русской и/илицерковнославянской фонетики: Aleksandr (церк. ${ }^{30}$ Александр) (1939[2], 1946[1], 1948[1]), Anatolij (церк. Анатолий) (1939[1], 1947[1]), Antonij (церк. Антоний) (1947[1], 1995[1]), Arkadij (церк. Аркадий) (1990[2], 1991[1], 1992[1], 1998[1]), Boris (церк. Борис) (1946[1], 1948[1]), Daniił (церк. Даниил) (1992[2], 1993[2], 1994[1], 1996[1], 1997[2]), Dorofiej (церк. Дорофей) (1990[1], 1991 [1], 1995[1]), Faddiej (церк. Фаддей) (1948[1]), Fieodor (церк. Феодор) (1939[1], 1946[1]), Foта (церк. Фома) (1990[1], 1993 [2], 1994[1], 1995[1], 1996[2], 1997[2]), Gieorgij (церк. Георгий) (1939[3], 1946[2], 1947[3], 1948[1]), Grigorij (церк. Григорий) (1992[1]), Iakow (церк. Иаков) (1990[1], 1992[1], 1993[4], 1996[1], 1997[1]), Igor' (церк. Игорь) (1997[1], 1998[1]), Iоann (церк. Иоанн) (1946[5], 1947[1],

что суффиксы с элементом -s-, которые не встречаются в системе имен польского языка, образовывали дериваты от христианских имен на Беларуси и на территории Подляшской земли: «-еs-: Matresa<Matrona, -es'-: Matresia<Matrona» (por. B. Tichoniuk, Imiona i ich formy..., s. 33-34).

29 Эти окончания появились, как можно предполагать, путем неправильной аналогии к другим, похожим по произношению и записи именам, напр. Прохорий - Григорий, Агафоний - Антоний. Таким способом это привело к смешению окончаний имен мужского рода на

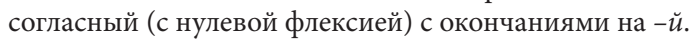

30 церк. - церковный. 
1948[3], 1990[1], 1993[1]), Iulian (церк. Иулиан) (1997[1]), Jewgienij (церк. Евгений) (1946[1], 1947[1]), Jewstafij (церк. Евстафий) (1947[1]), Kallimach (церк. Каллимах) (1997[1]), Kallinik (церк. Каллиник) (1994[2]), Konstantin (церк. Константин) (1946[1], 1994[1]), Kornilij (церк. Корнилий) (1995[1]), Leontij (церк. Леонтий) (1939[1]), Łuka (церк. Лука) (1993[1], 1994[1], 1995[2], 1996[1], 1997[1]), Mark (церк. Марк) (1991[1], 1994[1]), Martin (церк. Мартин) (1990[3], 1991[1], 1992[1], 1994[1]), Мatfiej (церк. Матфей) (1992[2], 1993[2], 1994[3], 1995[1], 1997[2], 2001[1]), Matfij (церк. Матфий) (1993[1], 1996[1]), Michait (церк. Михаил) (1939[2], 1946[1], 1947[1], 1948[3], 1990[1], 1992[1], 1993[1], 1994[1], 1995[1], 1996[1], 1999[1], 2003[1]), Nikita (церк. Никита) (2004[1]), Nikołaj (церк. Николай) (1947[1], 1948[5], 1993[1]), Patrikij (церк. Патрикий) (1992[1], 1993[2], 1996[1]), Pietr (церк. Петр) (1948[1], 1997[1]), Rafait (церк. Рафаил) (1991[1], 1993[4], 1994[1], 1997[1]), Simon (церк. Симон) (1992[1]), Stiefan (церк. Стефан) (1939[1]), Walentin (церк. Валентин) (1947[2]), Warfołomiej (церк. Варфоломей) (1994[2], 1995[3], 1996[2], 1997[1]), Wasilij (церк. Василий) (1939[3], 1948[1]), Witalij (церк. Виталий) (1947[1]), Władimir (церк. Владимир) (1939[1], 1946[2], 1947[3]); Ałł (церк. Алла) (1947[1], 1948[1], 1992[2], 1995[1]), Anastasija (церк. Анастасия) (2004[1]), Darija (церк. Дария) (1994[1]), Domna (церк. Домна) (1991[1]), Galina (церк. Галина) (1947[1]), Głafira (церк. Глафира) (1997[1]), Iоаппа (церк. Иоанна) (1990[1], 1993[2], 1994[1], 1996[1], 1997[1]), Irina (церк. Ирина) (1946[1], 1947[3], 1948[1]), Iulitta (церк. Иулитта) (1992[2], 1995[1]), Iиstina (церк. Иустина) (1992[1]), Jekatierina (церк. Екатерина) (1946[1], 1993[1], 1994[1], 1995[1]), Jelena (церк. Елена) (1947[2], 1948[1], 2006[1]), Jelisawieta (церк. Елисавета) (1939[1]), Јеwa (церк. Ева) (1994[1], 1995[1], 1996[1]), Jewgienija (церк. Евгения) (1948[1]), Kławdija (церк. Клавдия) (1948[1], 1999[1]), Lidija (церк. Лидия) (1947[1], 1948[1]), Lubow' (церк. Любовь) (1939[2], 1946[2]), Marfa (церк. Марфа) (1991[1], 1992[1], 1993[2], 1994[3], 1997[3], 1998[1]), Margarita (церк. Маргарита) (1990[1], 1991[1], 1992[4], 1995[3], 1996[1], 2001[1], 2004[1]), Marija (церк. Мария) (1939[2], 1947[1]), Marioniłła (церк. Марионилла) (1996[1]), Моiko (церк. Моико) (1991[1], 1993[1], 1995[1]), Nadieżda (церк. Надежда) (1939[1], 1947[1]), Nonпа (церк. Нонна) (1946[1]), Paraskiewa (церк. Параскева) (2001[1]), Pawła (церк. Павла) (1991[1], 1992 [3], 1993[3], 1994[1], 1995[1], 1996[1], 1997[1], 2000[1]), Sarra (церк. Сарра) (1994[1]), Susanna (церк. Сусанна) (1997[1]), Walentina (церк. Валентина) (1939[1], 1946[1], 1947[1], 1948[1]), Warwara (церк. Варвара) (1993[2]), Wiera (церк. Вера) (1991[1]), Wieronika (церк. Вероника) (2000[1]), Zinaida (церк. Зинаида) (1939[1], 1946[1]), Zoja (церк. Зоя) (1946[1], 1947[1]).

Довольно часто появляется запись в виде польского официального варианта: Aleksander (церк. Александр) (1946[2], 1993[1]), Aleksy (церк. Алексий) 
(1939[1]), Andrzej (церк. Андрей) (1991[1]), Arkadiusz (церк. Аркадий) (1991[1], 1998[1]), Daniel (церк. Даниил) (1990[3], 1991[1], 1994[1]), Emilian (церк. Емилиан) (1990[1]), Filip (церк. Филипn) (2002[1]), Łukasz (церк. Лука) (1990[1], 1991[2]), Масіеј (церк. Матфий) (1991[1]), Marcin (церк. Мартин) (1990[1], 1991[1], 1993[1]), Marek (церк. Марк) (1991[1]), Mateusz (церк. Матøей) (1990[1], 1991[1], 1993[1]), Michat (церк. Михаил) (1990[2], 1991[3]), Pawet (церк. Павел) (1939[1], 1990[4], 1991[2], 1992[2], 1993[2], 1994[3], 1995[2], 1996[2], 1997[1], 1998[1]), Piotr (церк. Петр) (1939[1], 1990[2], 1991[2], 1992[1], 1993[1], 1994[1], 1995[4], 2001[1]), Symeon (церк. Симеон) (1939[1]), Teоdor (церк. Феодор) (1939[1]); Barbara (церк. Варвара) (1990[1], 1991[1]), Dominika (церк. Домника) (1994[1]), Elżbieta (церк. Елисавета) (1990[1], 1991[1]), Emilia (церк. Емилия) (1992[1], 1995[1], 1996[1], 2000[1]), Irena (церк. Ирина) (1991[1]), Joапnа (церк. Иоанна) (1990[2], 2007[1]), Julita (церк. Иулитта) (1991[1]), Justyna (церк. Иустина) (1990[1], 1991[1]), Katarzyna (церк. Екатерина) (1990[2], 1991[4]), Klaudia (церк. Клавдия) (1991[1], 1993[1]), Małgorzata (церк. Маргарита) (1991[1]), Marta (церк. Марфа) (1991[2]), Nadzieja (церк. Надежда) (1990[1]), Walentyna (церк. Валентина) (1991[1]).

В качестве польского официального варианта появляются имена Borys (церк. Борис) (1946[1]), Dymitr (церк. Димитрий) (1991[1]). На самом деле трудно считать их „официальными польскими вариантами”, так как эти имена в польской (католической) среде почти не выступают. Как правило, они присущи восточной традиции.

Реже в польских записях употребляется транслитерация (более или менее точная), к которой следует причислить также попытки новейшей записи: Andrej (церк. Андрей) (1939[1]), Georgij (церк. Георгий) (1995[1]), Iakov (церк. Иаков) (1992[1], 1994[1]), Kesarij (церк. Кесарий) (1996[1]), Matfej (церк. Матфей) (1997[2]), Sevastian (церк. Севастиан) (1995[1]), Sewastian (церк. Севастиан) (1997[2]); Agafia (церк. Агафия) (1990[2], 1997[2]), Agnia (церк. Агния) (1990[4], 1991[1], 1992[2]), Angelina (церк. Ангелина) (1992[1], 1994[1], 1997[1]), Ekaterina (церк. Екатерина) (1994[1], 1995[2], 1996[1], 1997[3]), Elena (церк. Елена) (1995[1]), Elisaweta (церк. Елисавета) (1998[1]), Evdokia (церк. Евдокия) (1992[1]), Glikeria (церк. Гликерия) (1998[1]), Iulia (церк. Иулия) (1996[1]), Jekaterina (церк. Екатерина) (1995[1]), Łukia (церк. Лукия) (1998[1]).

Встречается также небольшое число записей, которые трудно включить в какую-нибудь группу. Некоторые из них отчасти напоминают русские церковные варианты, а также формы народно-разговорного или официальносветского оттенка, характеризующиеся наличием фонетических процессов, отличающих их от официальных форм церковных: Chrystofor (церк. Xристо- 
бор) (1993[1]), Dymitry (церк. Димитрий) (1939[1]), Joakim (церк. Иоаким) (1996[1]), Josif (церк. Иосиф) (1947[1]), Matwiej (церк. Матфей) (1994[1]), Rafael (церк. Рафбаил) (1990[2], 1991[1]), Siemieon (церк. Симеон) (1939[1]), Siergiej (церк. Сергий) (1946[1]), Iryna (церк. Ирина) (1946[1]), Iustinia (церк. Иустина) (1992[1], 1993[2], 1995[1]), Jekatieryna (церк. Екатерина) (1993[3]), Juliania (церк. Иулиания) (1991[1]), Julija (церк. Иулия) (1947[1]), Julitta (церк. Иулитта) (1996[1]), Lubow (церк. Любовь) (1947[2], 1948[1]), Łarysa (церк. Лариса) (2002[1]), Магја (церк. Мария) (1939[1]).

В приходских книгах, согласно церковному уставу, основной формой имени, данного при Св. Крещении, является форма каноническая. Однако, на основании исследуемого материала можно сказать, что в метрических записях присутствует довольно много примеров употребления других, нецерковных вариантов имен собственных. Это светские (Алексей, Пелагея), древнецерковные (Захарий, Катерина), народно-разговорные (Осип, Марианна), старокалендарные (Марко, Параскевия), сокращенные и другие формы смешанного типа (Игнати, Иулита).

Личные имена в своих производных формах обладают рядом грамматических черт. Среди фонетических особенностей, чаще всего встречается чередование гласных и согласных (Герасим - Гарасим, Лаврентий - Ваврентий), прибавление или редукция звуков (Ксения - Оксения, Кондрат Конрат), а также сокращение групп гласных и согласных (Даниил - Данило, Иоанн - Иоан) и смягчение или отвердение конечных звуков (Фекла - Фекля, Игорь - Игор). При морфологии имен собственных в производных вариантах стоит обратить внимание на флексию, т.е. на чередование, прибавление или редукцию конечных элементов (Алексий - Алексей, Агабон - Агабоний).

Среди имен, которые выступают в метрических книгах в польской записи, чаще всего встречаются примеры транскрипции (Wtadimir, Ioanna) или запись польского официального эквивалента (Marcin, Katarzyna). Появляются также примеры употребления транслитерации (Josif, Sevastian, Evdokia, Łukia). 


\section{Литература}

Abramowicz Z., Imiona chrzestne białostoczan w aspekcie socjolingwistycznym (lata 1885-1985), Białystok 1993.

Abramowicz Z., Citko L., Dacewicz L., Stownik historycznych nazw osobowych Białostocczyzny (XV-XVII w.), t. 1-2, Białystok 1997-1998.

Bazylow L., Historia Rosji, t. I, Warszawa 1985.

Citko L., Nazewnictwo osobowe pótnocnego Podlasia w XVI w., Białystok 2001.

Domin J., Z zagadnień słowotwórstwa antroponimów we współczesnym języku rosyjskim, „Zeszyty Naukowe Wydziału Humanistycznego. FR", zeszyt 7/1978.

Fros H., Twoje imię: przewodnik onomastyczno-hagiograficzny, Kraków 1975.

Kalendarz Prawosławny 2007, Wydanie Warszawskiej Metropolii Prawosławnej.

Ławrinienko A., Historia języka rosyjskiego, cz. II, Rzeszów 1992.

Sosna G., Fionik D., Dzieje Cerkwi w Bielsku Podlaskim, Białystok 1995.

Spis imion prawosławnych w brzmieniu polskim i staro-cerkiewno-słowiańskim, Warszawa 1936.

Tichoniuk B., Imiona i ich formy na pograniczu polsko-białoruskim od XVI wieku do roku 1839, Zielona Góra 2000.

Булгаков С. В., Настольная книга для священно-иерковно-служителей, т. 2, Москва 1993 (репринтное воспроизведение издания 1913 г.).

Петровский Н. А., Словарь русских тичных имен, Москва 1984.

Суперанская А. В., Словарь русских тичных имен, Москва 1998.

Суслова А. В., Суперанская А. В., О русских именах, Ленинград 1978.

Тихонов А. Н., Бояринова Л. З., Рыжкова А. Г., Словарь русских личных имен, Москва 1995. Требникъ, Варшава 1925. 